\title{
Risk factors for kidney cancer in New South Wales. IV. Occupation
}

\author{
Margaret McCredie, J H Stewart
}

\begin{abstract}
In a population based case-control study of kidney cancer in New South Wales, data from structured interviews with 489 cases of renal cell cancer (RCC), 147 cases of renal pelvic cancer (CaRP), and 523 controls from the electoral roles were obtained about employment in certain industries or occupations, and exposure to particular chemicals chosen because of suspected associations with kidney cancer. A low level of education increased the risk for CaRP but not RCC. After adjustment for known risk factors, exposure to asbestos significantly increased the risk for RCC (relative risk $(R R)=1 \cdot 62 ; 95 \%$ confidence interval (95\% CI) $1 \cdot 04-2 \cdot 53)$. Working in the dry cleaning industry had a stronger link with CaRP (RR $=4 \cdot 68 ; 95 \%$ CI 1.32-16.56) than with $\operatorname{RCC}(\mathbf{R R}=2 \cdot 49 ; 95 \%$ CI 0.97-6.35). Working in the iron and steel industry doubled the risk for CaRP (RR $=2 \cdot 13 ; 95 \%$ CI $1.04-4 \cdot 39$ ) whereas employment in the petroleum refining industry had a non-significant association with CaRP (RR $=2 \cdot 60 ; 95 \%$ CI 0.88-7.63) and none with RCC.
\end{abstract}

(British Journal of Industrial Medicine 1993;50:349-354)

Despite the variety of industries concerned (dyeing, rubber and tyre manufacture, electrical and leather industries), the basis of occupationally induced urothelial cancers (bladder, renal pelvis, and ureter) is essentially known and understood-the implicated chemicals are for the most part aromatic amines for which a recognised mechanism exists. ${ }^{1}$ By contrast, none of the occupational risks postulated for cancer of the renal parenchyma (renal cell cancer (RCC)) have been found consistently in population based studies. $^{2-15}$

NSW Central Cancer Registry and Cancer Epidemiology Research Unit, NSW Cancer Council $M$ McCredie

Western Clinical School, University of Sydney, New South Wales, Australia

J H Stewart
The risk for RCC associated with working in specified industries or with occupational exposure to particular chemicals (chosen because of suspected associations with kidney cancer) has been examined in an international collaborative population based case-control study coordinated by the US National Cancer Institute. The participating centres, either in areas of high incidence of RCC or with a particular interest in kidney cancer, were in the United States (Minnesota), Denmark, Sweden, Germany (two centres), and Australia (New South Wales). The analysis of results from New South Wales pertaining to these factors are presented here together with findings for cancer of the renal pelvis.

\section{Methods}

Potential cases comprised all incident cases in 198990 of cancer of the renal parenchyma (ICD-9 189.0) and renal pelvis (ICD-9 189.1) in residents of New South Wales who were aged 20-79 at diagnosis; control subjects were selected from the electoral rolls using proportional random sampling based on the expected age distribution of the cases. The study population was confined to subjects whose names were in a current electoral roll, whose telephone number could be found, and who could speak English.

Cases were identified through statutory notification to the New South Wales Central Cancer Registry by hospitals, pathology laboratories, and radiotherapy departments ${ }^{16}$ as well as by regular contact with urologists throughout New South Wales. Up to 31 July 1991 (allowing for late notifications) 744 eligible cases of RCC and 200 of CaRP were identified. Permission was requested from the attending doctor for inclusion in the study, followed by a letter to the case seeking participation. The release of information from the Cancer Registry was conditional upon adherence to a strict protocol that did not permit repeated approaches to either the doctor or the patient; nor could information be obtained from relatives of the patients. For RCC, loss of cases due to death $(23 \%)$, refusal (doctor $2 \%$, patient $1 \%$ ), or non-response (doctor $1 \%$, patient $5 \%$ ) resulted in a case group comprising 322 men and 181 women. For CaRP, 59 men and 90 women were interviewed. 
Death $(15 \%)$, refusal by doctor $(1 \%)$ or patient $(5 \%)$, and non-response by doctor $(3 \%)$ or patient $(2 \%)$ accounted for the rest. In each of the 12 five year age groups between 20 and 79, the percentages of the potential RCC cases who participated were 80,100 , $83,77,79,78,75,79,74,65,55$, and 47 respectively. For CaRP, the percentages who participated in the nine five year age groups between 35 and 79 were 100 , $100,89,89,84,90,74,58$, and 59 .

The diagnosis of interviewed cases was based on histopathology of the kidney (87\% RCC, $92 \%$ $\mathrm{CaRP})$ or other tissue ( $1 \% \mathrm{RCC})$, fine needle aspiration cytology of the kidney ( $4 \% \mathrm{RCC})$, or by computerised tomography, ultrasound, or contrast radiography ( $8 \%$ of each).

Of the proportional random sample obtained from the current New South Wales electoral rolls, telephone numbers were found for 803 . An initial letter seeking participation was followed up, if necessary, by a second letter and up to 10 telephone calls. The information on the rolls was out of date for 60 subjects ( 52 moved, eight dead) and 18 could not speak English. Of the remaining $725,74 \%$ were interviewed, the rest comprising refusals (no reason $16 \%$, ill health $7 \%$, other reason $2 \%$, senility $<1 \%$ ) and non-respondents $(2 \%)$. Among men, the proportions of interviewed controls in each 10 year age group were not significantly different from those of the non-respondents $\left(\chi^{2}=1.03, \mathrm{df}=3, \mathrm{p}=0.79\right)$ but the women who were not interviewed were slightly older than those who were (65 (SD 8) $v 62$ (SD 9) years, $t=3.092, d f=389, p<0.001)$.

One trained interviewer carried out all the interviews between May 1989 and July 1991. All but 10 of the cases (seven RCC, three CaRP) were interviewed within one year of diagnosis $(55 \%, 87 \%$, and $96 \%$ within three, six, and nine months of diagnosis respectively). Face to face interviews were held in the homes of all subjects who lived in the Sydney Metropolitan area (256 RCC, 71 CaRP, 232 controls). For subjects living in the rest of New South Wales (233 RCC, 76 CaRP, 291 controls), the checklists to be used with the standard questionnaire were mailed with a request to keep them unopened but accessible for a subsequent telephone interview. Self administered questionnaires were completed by 14 RCC cases, two CaRP cases, and 12 controls as this was the only means by which these subjects would participate.

The questionnaire (core questions identical with those used in the other collaborating centres) sought information about employment in certain industries and occupations and exposure to particular chemicals chosen because of suspected associations with kidney cancer, as well as data about other suspected risk factors and confounders. Demographic data including years of formal schooling and whether or not subjects had received technical or vocational training or attended university were also requested.

\section{Analysis}

Initial evaluation included inspection of frequencies of the variables. As the 28 self administered questionnaires contained an unacceptably high level of missing data, it was decided to restrict the analysis to the 489 cases and 523 controls who were interviewed either face to face or by telephone. Tertiles of exposure variables were calculated on the basis of their distribution in the entire control group; tertiles for age were based on cases and controls combined.

Relative risks (RRs), together with 95\% confidence intervals $(95 \% \mathrm{CIs})$, were estimated from

Table 1 Characteristics of cases and controls for age, marital state, and education, New South Wales, 1989-90

\begin{tabular}{|c|c|c|c|c|c|c|}
\hline & \multicolumn{2}{|c|}{ Population controls } & \multicolumn{2}{|c|}{ Renal cell cancer } & \multicolumn{2}{|c|}{ Renal pelvic cancer } \\
\hline & $\begin{array}{l}\text { Men } \\
(n=231)\end{array}$ & $\begin{array}{l}\text { Women } \\
(n=292)\end{array}$ & $\begin{array}{l}\text { Men } \\
(n=310)\end{array}$ & $\begin{array}{l}\text { Women } \\
(n=179)\end{array}$ & $\begin{array}{l}\text { Men } \\
(n=58)\end{array}$ & $\begin{array}{l}\text { Women } \\
(n=89)\end{array}$ \\
\hline $\begin{array}{r}\text { Age }(y): \\
20-29 \\
30-39 \\
40-49 \\
50-59 \\
60-69 \\
70-79\end{array}$ & $\begin{array}{rr}0 & \\
6 & (2 \cdot 6 \%) \\
26 & (11 \cdot 3 \%) \\
54 & (23 \cdot 4 \%) \\
87 & (37 \cdot 7 \%) \\
58 & (25 \cdot 1 \%)\end{array}$ & $\begin{array}{rr}0 & \\
7 & (2.4 \%) \\
20 & (6.8 \%) \\
80 & (27.4 \%) \\
102 & (34.9 \%) \\
83 & (28.4 \%)\end{array}$ & $\begin{array}{r}2(0.6 \%) \\
13(4.2 \%) \\
43(13.9 \%) \\
68(21.9 \%) \\
116(37.4 \%) \\
68(21.9 \%)\end{array}$ & $\begin{array}{rr}3 & (1 \cdot 7 \%) \\
3 & (1 \cdot 7 \%) \\
24 & (13 \cdot 4 \%) \\
52 & (29 \cdot 1 \%) \\
58 & (32 \cdot 4 \%) \\
39 & (21 \cdot 8 \%)\end{array}$ & $\begin{array}{rr}0 & \\
3 & (5 \cdot 2 \%) \\
6 & (10 \cdot 3 \%) \\
7 & (12 \cdot 1 \%) \\
27 & (46 \cdot 6 \%) \\
15 & (25 \cdot 9 \%)\end{array}$ & $\begin{array}{rr}0 & \\
0 & \\
3 & (3 \cdot 4 \%) \\
17 & (19 \cdot 1 \%) \\
41 & (46 \cdot 1 \%) \\
28 & (31 \cdot 5 \%)\end{array}$ \\
\hline $\begin{array}{l}\text { Marital state: } \\
\text { Ever married }\end{array}$ & $222(96 \cdot 1 \%)$ & $281(96 \cdot 2 \%)$ & $292(94 \cdot 2 \%)$ & $169(94.4 \%)$ & $55(94 \cdot 8 \%)$ & $87(97 \cdot 8 \%)$ \\
\hline $\begin{array}{l}\text { Educational level: } \\
\leqslant 6 \text { years at school } \\
7-10 \text { years at school } \\
\geqslant 11 \text { years at school } \\
\text { Vocational or technical } \\
\text { training } \\
\text { University degree }\end{array}$ & $\begin{array}{rr}13 & (5.6 \%) \\
53 & (22.9 \%) \\
14 & (6.1 \%) \\
& \\
120 & (51.9 \%) \\
31 & (13.4 \%)\end{array}$ & $\begin{array}{rr}26 & (8.9 \%) \\
115 & (39.4 \%) \\
20 & (6.8 \%) \\
& \\
119 & (40.8 \%) \\
12 & (4.1 \%)\end{array}$ & $\begin{array}{rr}18 & (5 \cdot 8 \%) \\
82 & (26.5 \%) \\
21 & (6 \cdot 8 \%) \\
& \\
164 & (52.9 \%) \\
25 & (8 \cdot 1 \%)\end{array}$ & $\begin{array}{rr}17 & (9 \cdot 5 \%) \\
71 & (39 \cdot 7 \%) \\
9 & (5 \cdot 0 \%) \\
& \\
73 & (40 \cdot 8 \%) \\
9 & (5 \cdot 0 \%)\end{array}$ & $\begin{array}{rr}5 & (8 \cdot 6 \%) \\
19 & (32 \cdot 8 \%) \\
2 & (3.4 \%) \\
& \\
31 & (53.4 \%) \\
1 & (1.7 \%)\end{array}$ & $\begin{array}{rr}7 & (7 \cdot 9 \%) \\
55 & (61.8 \%) \\
2 & (2 \cdot 2 \%) \\
& \\
23 & (25 \cdot 8 \%) \\
2 & (2 \cdot 2 \%)\end{array}$ \\
\hline
\end{tabular}

^Mutually exclusive categories; subjects allocated to highest level for which they qualify. 
Table 2 Risk ratios for kidney cancer associated with certain occupations, New South Wales, 1989-90

\begin{tabular}{|c|c|c|c|c|c|c|c|}
\hline \multirow{4}{*}{$\begin{array}{l}\text { Employment in/as } \\
\text { Petroleum refining industry } \\
\text { Blast furnaces and coke ovens }\end{array}$} & \multirow{4}{*}{$\begin{array}{l}\text { Population } \\
\text { controls }(n=523) \\
\text { No exposed } \\
11 \\
23\end{array}$} & \multicolumn{3}{|c|}{ Renal cell cancer $(n=489)$} & \multicolumn{3}{|c|}{ Renal pelvic cancer ( $n=147)$} \\
\hline & & \multirow{2}{*}{$\begin{array}{l}\text { No } \\
\text { exposed } \\
15\end{array}$} & \multicolumn{2}{|c|}{$R R^{\star}(95 \% C I)$} & \multirow{3}{*}{$\begin{array}{l}\begin{array}{l}\text { No } \\
\text { exposed }\end{array} \\
8 \\
9\end{array}$} & \multicolumn{2}{|c|}{$R R^{+}(95 \% C I)$} \\
\hline & & & 1.01 & $(0 \cdot 45-2 \cdot 25)$ & & 2.97 & $(1.10-8.02)$ \\
\hline & & 36 & $1 \cdot 24$ & $(0 \cdot 71-2 \cdot 16)$ & & 1.89 & $(0.80-4.46)$ \\
\hline Iron and steel industry & 39 & 52 & $1 \cdot 18$ & $(0 \cdot 75-1 \cdot 85)$ & 19 & $2 \cdot 39$ & $(1.26-4.52)$ \\
\hline Dry cleaning industry & 7 & 16 & $2 \cdot 70$ & $(1 \cdot 08-6 \cdot 72)$ & 8 & 6.09 & $(1.95-18.90)$ \\
\hline Printing or graphics industry & 24 & 29 & $1 \cdot 18$ & $(0 \cdot 67-2 \cdot 08)$ & 6 & $0 \cdot 82$ & $(0 \cdot 32-2 \cdot 11)$ \\
\hline Machinist or tool maker & 34 & 48 & $1 \cdot 15$ & $(0 \cdot 72-1 \cdot 86)$ & 16 & 1.83 & $(0.92-3.61)$ \\
\hline Welder & 24 & 40 & 1.37 & $(0 \cdot 80-2 \cdot 34)$ & 8 & 1.66 & $(0.68-4.03)$ \\
\hline Dentist & 4 & 1 & 0.34 & $(0 \cdot 04-3 \cdot 16)$ & 0 & & \\
\hline Physician & 7 & 4 & 0.48 & $(0 \cdot 14-1 \cdot 70)$ & 0 & & \\
\hline Petrol station attendant & 32 & 25 & 0.69 & $(0 \cdot 40-1 \cdot 21)$ & 9 & 1.03 & $(0.46-2.30)$ \\
\hline
\end{tabular}

*Adjusted for age, sex, method of interview, tand education.

multivariate logistic regression by EGRET ${ }^{17}$ according to Breslow and Day. ${ }^{18}$ All estimates of risk for RCC were adjusted for age (in tertiles), sex, and method of interview. The effect of each factor and of potential interactions were tested by the likelihood ratio test. All factors with a statistically significant influence were included in the final model to estimate the effect of each factor adjusted for all other significant factors.

With case:control ratios of roughly 1:1 for RCC and $1: 3.5$ for CaRP, the study was big enough to have $90 \%$ power to detect an unadjusted RR of about 2.0 , given a one sided significance level of 0.05 and $10 \%$ of the controls exposed to the risk factor of interest. ${ }^{18}$

\section{Results}

Table 1 describes the cases and controls in respect of age, marital state, and educational level. Almost one fifth of RCC cases were aged less than 50 at diagnosis. Cases and controls were similar in the proportions who had ever been married. Although the educational levels achieved were broadly similar between RCC cases and the controls, more male controls had a university degree. Inclusion of a term for education into a logistic regression model (adjusted for age, sex, and method of interview), however, did not indicate an association; nor was there a trend of decreasing risk with increasing level of education. Cases of CaRP were less well educated than controls, and inclusion of a term for education made a significant contribution $\left(\chi^{2}=6.60, p=0.01\right)$ to a model also adjusted for two known risk factors-namely, cigarette smoking, ${ }^{19}$ and analgesics containing phenacetin. $^{20}$

Table 2 gives the numbers of subjects answering yes to the series of questions "Have you ever been employed in the (named) industry, or as a (named occupation)?" It also gives an adjusted risk ratio for each type of cancer. Similarly, table 3 presents responses to the question "Were you ever exposed to (material) while working on a job that you held for one year or longer?" Significantly raised RRs were found for the dry cleaning industry (both types of cancer), the iron and steel industry (CaRP), the petroleum refining industry $(\mathrm{CaRP})$, and exposure to asbestos (RCC), solvents (RCC), cutting oils or mists (RCC), or other petroleum products (both types of cancer). When these factors were adjusted for each other and for known risk factors for RCC or CaRP, however (table 4), most associations were no longer significant.

\section{ASBESTOS}

Exposure to asbestos significantly increased the risk

Table 3 Risk ratios for kidney cancer associated with occupational exposures, New South Wales, 1989-90

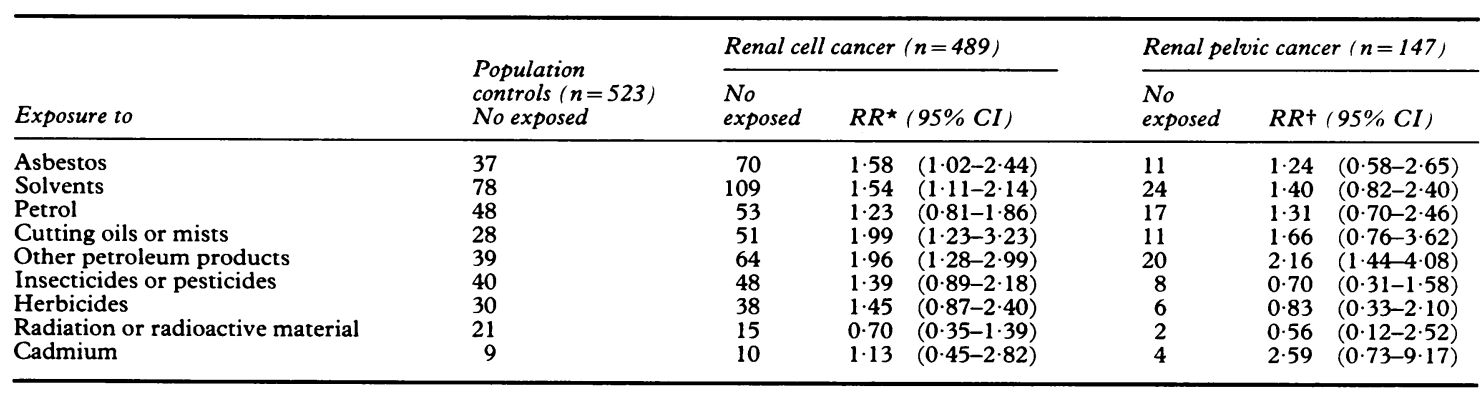

^Adjusted for age, sex, method of interview, tand education. 
Table 4 Occupational risk factors for kidney cancer, New South Wales, 1989-90

\begin{tabular}{|c|c|c|}
\hline & Renal cell cancer & Renal pelvic cancer \\
\hline & $R R^{\star}(95 \% C I)$ & $R R+(95 \% C I)$ \\
\hline \multirow{4}{*}{$\begin{array}{l}\text { Exposure to asbestos } \\
\text { Dry cleaning industry } \\
\text { Iron and steel industry } \\
\text { Petroleum refining } \\
\quad \text { industry }\end{array}$} & $1.62(1.04-2.53)$ & - \\
\hline & $2.49(0.97-6.35)$ & $4.68(1.32-16.56)$ \\
\hline & - & \\
\hline & - & $2.60(0.88-7.63)$ \\
\hline
\end{tabular}

*Adjusted for age, sex, method of interview and cigarette smoking, and *body mass index or teducation and phenacetin containing analgesics.

for RCC by a factor of 1.6 (table 4 ), a link seen more clearly among men $(R R=1 \cdot 73,95 \%$ CI $1 \cdot 04-2 \cdot 89$; 64 cases, 32 controls) than women $(R R=1 \cdot 17,95 \%$ CI 0.30-4.55; five cases, five controls). With simultaneous adjustment for duration of exposure and year exposure began in a logistic model including only subjects who had ever been exposed to asbestos, the risk for RCC was fivefold higher in those whose exposure began after rather than before 1956 (table 5).

\section{DRY CLEANING INDUSTRY}

The risk of both types of kidney cancer was increased by working in the dry cleaning industry (table 4 ), the effect on CaRP $(\mathrm{RR}=4.68 ; 95 \% \mathrm{CI} 1.32-16.56$; two male and six female cases, two male and five female controls) being almost twice as great as that for RCC $(R R=2 \cdot 49 ; 95 \%$ CI 0.97-6.35; eight male and eight female cases).

\section{IRON AND STEEL INDUSTRY}

Working in the iron and steel industry doubled the risk for CaRP (table 4). When only subjects who had worked in this industry ( 17 male, two female cases; 31 male, eight female controls) were considered, simultaneous modelling of tertiles of duration of work (1$5,6-21, \geqslant 22$ years) and of the year work began in the

Table 5 Risks of renal cell cancer associated with exposure to asbestos, New South Wales, 1989-90

\begin{tabular}{llll}
\hline $\begin{array}{l}\text { Subjects } \\
\text { exposed } \\
\text { to asbestos }\end{array}$ & $\begin{array}{l}\text { No of } \\
\text { exposed } \\
\text { controls }\end{array}$ & $\begin{array}{l}\text { No of } \\
\text { exposed } \\
\text { cases }\end{array}$ & $R R+(95 \%$ CI) \\
\hline $\begin{array}{l}\text { Duration of exposure (y): } \\
1-3\end{array}$ & 11 & 15 & 1 \\
$4-15$ & 11 & 25 & $2 \cdot 23(0.68-7 \cdot 34)$ \\
$\geqslant 16$ & 14 & 27 & $2.09(0.64-6.76)$ \\
& & & \\
Year exposure began: & 14 & 20 & 1 \\
$1929-48$ & 11 & 15 & $1.04(0.35-3.09)$ \\
$1949-55$ & 11 & 32 & $5.28(1.43-19.55)$ \\
$1956-86$ & & & \\
\hline
\end{tabular}

*Three cases and one control gave no information on period of exposure.

tModel includes both time related exposure variables as well as terms for age, sex, and method of interview. industry (1930-41, 1942-56, 1957-86) showed no trend in risk for CaRP.

\section{PETROLEUM REFINING INDUSTRY}

A 2.6-fold increased risk for CaRP was linked with the petroleum refining industry (table 4 ). The small numbers of subjects (eight men with CaRP; nine male and two female controls) reporting this type of work prevented analysis by duration or period of employment. No association was seen with RCC.

\section{Discussion}

This Australian study confirms associations between kidney cancer and exposure to asbestos, and work in the petroleum, iron and steel, and dry cleaning industries reported predominantly in North America and Europe.

Support for asbestos as a risk factor for kidney cancer has been provided by cohort studies of workers involved in insulation, ${ }^{4}$ production of asbestos, ${ }^{12}$ and shipyards (Puntoni et al 1979 reviewed by Smith et $\left.a l^{21}\right)$, each of which showed a significant standardised mortality ratio (SMR) of between 1.7 and 2.7. A case-control study of shipyard workers found an adjusted incidence rate ratio for RCC that remained in the range 1.5-2.0 depending upon the criteria of exposure. ${ }^{9}$ Evidence for asbestos fibres reaching the kidney has been furnished by necropsy studies of humans and of rats fed asbestos by gavage; and asbestos fibres have been found in human urine (reviewed by Smith et $a l^{21}$ ). Moreover, experimental studies have found asbestos to be a carcinogen for the kidney in the rat. ${ }^{22}$ In the present study a link with asbestos was present only in men, the risk ratio of 1.73 being of the same order as those found previously. A higher risk was found in those exposed since compared with before 1956. As litigation seeking compensation for asbestos induced disease has been widely publicised in Australia it is possible that recall bias in this study might explain the association with exposure to asbestos. That the association was found with RCC but not with CaRP indicates a specific, and therefore real, link. The Minnesota case-control study found no association of asbestos with either $\mathrm{RCC}^{5}$ or $\mathrm{CaRP}{ }^{23}$

A further suspected occupational link with kidney cancer has been exposure to hydrocarbons through work in the petroleum or iron and steel industries. Whereas renal tumours in rats have developed after long term inhalation of gasoline vapours, ${ }^{24}$ cohort studies of petroleum industry employees have found no evidence for an increased risk of kidney cancer except perhaps for drivers distributing petroleum products (reviewed by Wong and Raabe ${ }^{25}$ and Enterline and Viren ${ }^{26}$ ), and conflicting findings have emerged from case-control studies. ${ }^{71026}$ Men working with coke ovens had a higher than expected 
mortality from RCC (based on eight deaths) in a cohort study of steel workers ${ }^{2}$ whereas case-control investigations of RCC reported contradictory results for exposures defined as petroleum, tar, and pitch products, ${ }^{527}$ burning coal, $^{28}$ and occupational exposure to hydrocarbons ${ }^{14}$ In the present study no association was found between RCC and working in these industries, the increased risk seen for those exposed to other petroleum products and to cutting oils and mists disappearing when adjustment was made in the analysis for other risk factors. By contrast, independent significant twofold raised risks for CaRP were linked with ever being employed in the petroleum industry, and iron or steel industries. Small numbers prevented analysis by duration of employment in the first industry, and no trend was found for the second. Other case-control studies of urothelial cancer, however, also found similar associations; specificially, significantly increased risks for exposure to mineral or cutting oils ( $R R=$ 2.8; renal pelvis $\left.{ }^{23}\right)$; coal and coke $(R R=4.0)$, and asphalt and $\operatorname{tar}\left(R R=5.5\right.$; renal pelvis and ureter $\left.{ }^{29}\right)$; and for exposure to benzene $(R R=2.0$; mainly bladder ${ }^{30}$ ).

Suggestions of an increased risk of kidney cancer in the dry cleaning industry (another source of hydrocarbons-for example, Blair 1979, quoted in Blair et $a^{15}$ ) were not confirmed in a recent cohort study of dry cleaning workers. ${ }^{15}$ Whereas no association of RCC and organic solvents was found in one small case-control study, ${ }^{13}$ an excess risk was found in female dry cleaners in another. ${ }^{10}$ Significant fourfold and twofold increased risks for CaRP and RCC respectively were found in the current study; recall bias cannot be ruled out as an explanation.

Although a twofold increased risk of RCC has been attributed to occupational exposure to cadmium, ${ }^{3}$ this finding has not been replicated in this or other studies. ${ }^{510}$ Neither could we show a raised risk for RCC among physicians and dentists (the reverse was true) by contrast with the Swedish study linking cancer incidence (1961-79) and census data (1960) that found increased risks among several professional and white collar occupations including physicians and others in the health care industry. ${ }^{11} \mathrm{~A}$ high proportional incidence ratio for RCC has been found in another professional group, architects, in Los Angeles County incidence data for 1972-86. ${ }^{31}$ Subjects were not asked about employment in the leather industry so that the possibility of increased risks for $\mathrm{RCC}^{5}$ as well as $\mathrm{CaRP}^{232}$ could not be determined.

With respect to the educational level achieved, subjects in this investigation resembled those in previous studies of RCC in which only slight differences, if any, were found between cases and controls. ${ }^{581027}$ By contrast, a greater proportion of cases with CaRP than controls with low educational level was found for both sexes in this and an earlier study in NSW ${ }^{20}$ but only among men in the Minnesota survey. ${ }^{23}$

In this study subjects were not asked for a detailed occupational history as the main hypotheses were directed at other possible aetiological factors. Although information was gathered about the most recent and the usual occupation, this was not used in the present analysis, which was based on specific questions relating to industries or exposures under suspicion through other epidemiological studies. Drawbacks of the present investigation include small numbers of exposed subjects, no validation of the self reported exposures, and no possibility of categorising exposures by intensity. Nevertheless, as each of the associations positively identified here has substantial supportive evidence from other studies or known mechanisms of renal or urothelial carcinogenesis, our results do contribute to the overall understanding of occupationally related renal neoplasms.

The project was supported by the National Health and Medical Research Council of Australia, the Government Employees Assistance to Medical Research Fund, and the Australian Kidney Foundation. We are grateful to Professor D Raghavan, now at Roswell Park Cancer Institute, Buffalo, for his participation in the design of this study; to the urologists of New South Wales for permission to include their patients in this study; to Mrs Joy Gillies for conducting the interviews with all the cases and controls; and to Mrs Lesley Porter for coding the questionnaires and all data entry.

Requests for reprints to: Dr Margaret McCredie, NSW Central Cancer Registry and Cancer Epidemiology Research Unit, NSW Cancer Council, 153 Dowling Street, Woolloomooloo, NSW 2011, Australia.

1 Franks LM, Teich N. Introduction to the cellular and molecular biology of cancer. Oxford: Oxford University Press, 1988.

2 Redmond CK, Ciocco A, Lloyd JW, et al. Long-term mortality study of steelworkers. VI. Mortality from malignant neoplasms among coke oven workers. J Occup Med 1972;14: 621-9.

3 Kolonel LN. Association of cadmium with renal cancer. Cancer 1976;37:1782-7.

4 Selikoff IJ, Hammond EC, Seidman H. Mortality experience of insulation workers in the United States and Canada, 19431976. Ann NY Acad Sci 1979;330:1-116.

5 McLaughlin JK, Mandel JS, Blot WJ, Schuman LM, Mehl ES, Fraumeni JF Jr. A population-based case-control study of renal cell carcinoma. J Natl Cancer. Inst 1984;72:275-84.

6 Malker HR, Malker BK, McLaughlin JK, Blot WJ. Kidney cancer among leather workers. (letter) Lancet 1984;i:56.

7 McLaughlin JK, Blot WJ, Mehl ES, Stewart PA, Venable FS, Fraumeni JF Jr. Petroleum-related employment and renal cell cancer. J Occup Med 1985;27:672-4.

8 Yu MC, Mack TM, Hanisch R, Cicioni C, Henderson BE. Cigarette smoking, obesity, diuretic use, and coffee consumption as risk factors for renal cell carcinoma. J Natl Cancer Inst 1986;77:351-6.

9 Maclure $M$. Asbestos and renal adenocarcinoma: a case-control study. Environ Res 1987;42:353-61.

10 Asal NR, Geyer JR, Risser DR, Lee ET, Kadamani S, Cherng 
N. Risk factors in renal cell carcinoma. II. Medical history, occupation, multivariate analysis, and conclusions. Cancer Detect Prev 1988;13:263-79.

11 McLaughlin JK, Malker HSR, Stone BJ, et al. Occupational risks for renal cancer in Sweden. Br J Ind Med 1987;44 $119-23$.

12 Enterline PE, Hartley J, Henderson V. Asbestos and cancer: a cohort followed up to death. Br J Ind Med 1987;44:396-410.

13 Harrington JM, Whitby H, Gray CN, Reid FJ, Aw TC, Waterhouse JA. Renal disease and occupatinal exposure to organic solvents: a case referent approach. Br J Ind Med 1989;46:643-50.

14 Kadamani S, Asal NR, Nelson RY. Occupational hydrocarbon exposure and risk of renal cell carcinoma. $A m \mathrm{~J}$ Ind Med 1989;15:131-41.

15 Blair A, Stewart PA, Tolbert PE, et al. Cancer and other causes of death among a cohort of dry cleaners. $\mathrm{Br} J$ Ind Med 1990;47:162-8.

16 McCredie $M$, Coates $M$, Churches $T$, Taylor R. Cancer incidence in New South Wales, Australia. Eur $J$ Cancer 1991;27:928-31.

17 Statistics and Epidemiology Research Corporation. EGRET: Epidemiological graphics, estimation, and testing. Seattle, $W A$ : Statistics and Epidemiology Research Corporation, 1990.

18 Breslow NE, Day NE. Statistical methods in cancer research. Vol I. The analysis of case-control studies. Lyon: International Agency for Research on Cancer, 1980.

19 McCredie M, Stewart JH. Risk factors for kidney cancer in New South Wales. I. Cigarette smoking. Eur J Cancer 1992 (in press).

20 McCredie M, Stewart JH, Ford JM, MacLennan RA. Phenacetin-containing analgesics and cancer of the bladder or renal pelvis in women. Br J Urol 1983;55:220-4.

21 Smith AH, Shearn VI, Wood R. Asbestos and kidney cancer: the evidence supports a causal association. Am J Ind Med 1989;16:159-66.
22 International Agency for Research on Cancer. Asbestos. IARC Monogr Eval Carcinog Risks Hum 1977;14:42.

23 McLaughlin JK, Blot WJ, Mandel JS, Schumann LM, Mehl ES, Fraumeni JF Jr. Etiology of cancer of the renal pelvis. $J$ Natl Cancer Inst 1983;71:287-91.

24 MacFarland HN, Ulrich CF, Holdsworth CE, et al. A chronic inhalation study with unleaded gasoline vapour. Journal of the American College of Toxicology 1984;3:231-48.

25 Wong O, Raabe GK. Critical review of cancer epidemiology in petroleum industry employees, with a quantitative metaanalysis by cancer site. Am J Ind Med 1989;15:283-310.

26 Enterline PE, Viren J. Epidemiologic evidence for an association between gasoline and kidney cancer. Environ Health Perspect 1985;62:303-12.

27 Goodman MT, Morgenstern H, Wynder EL. A case-control study of factors affecting the development of rnal cell cancer. Am J Epidemiol 1986;124:926-41.

28 Sharpe CR, Rochon JE, Adam JM, Suissa S. Case-control study of hydrocarbon exposures in patients with renal cell carcinoma. Can Med Assoc J 1989;140:1309-18.

29 Jensen OM, Knudsen JB, McLaughlin JK, Sørensen BL. The Copenhagen case-control study of renal pelvis and ureter cancer: role of smoking and occupational exposures. Int $J$ Cancer 1988;41:557-61.

30 Steineck G, Plato N, Gerhardsson M, Norell SE, Hogstedt C. increased risk of urothelial cancer in Stockholm during 198587 after exposure to benzene and exhausts. Int $J$ Cancer 1990;45:1012-7.

31 Lowery JT, Peters JM, Deapen D, London SJ. Renal cell carcinoma among architects. Am J Ind Med 1991;20:123-5.

32 Schmauz R, Cole P. Epidemiology of cancer of the renal pelvis and ureter. J Natl Cancer Inst 1974;52:1431-4.

Accepted 21 July 1992 